\title{
Genetic Recombination by Spheroplast Fusion of Sterol-transforming Mycobacterium Strains
}

\author{
By ANTÓNIA JEKKEL, * ÉVA CSAJÁGI, ÉVA ILKÖY \\ AND GÁBOR AMBRUS \\ Department of Microbiology, Institute for Drug Research, POB 82, Budapest 1325, Hungary
}

(Received 26 September 1988; revised 15 February 1989; accepted 2 March 1989)

\begin{abstract}
Wall-deficient forms of fast-growing mycobacteria were produced in growth medium containing vancomycin and glycine, and spheroplasts were prepared by lysozyme treatment of wall-deficient cells. Spheroplasts gave rise to recombinants with high frequency $(2-6 \%)$ when they were fused using polyethylene glycol 6000 . The results demonstrated that in vivo genetic recombination could be used to produce genetically modified Mycobacterium strains with applications in transformation of steroids. Useful intermediates of steroid drug synthesis and new degradation products were obtained from sterols by selected recombinant strains.
\end{abstract}

\section{INTRODUCTION}

Mycobacteria are widely used in microbiological transformation of steroids (Schubert et al., 1961; Wix et al., 1968; Ambrus \& Büki, 1969) and hydrocarbons (Habets-Crutzen et al., 1985). Classical mutagenic techniques have been successfully applied to strain improvement of steroidtransforming mycobacteria, resulting in industrially important strains which degrade naturally occurring sterols to produce intermediates for the synthesis of steroid drugs (Marsheck et al., 1972; Wovcha et al., 1978).

Limited or no success has been achieved in gene transfer by conjugation in different Mycobacterium spp. (Mizuguchi \& Tokunaga, 1971; Koniček \& Koničkova-Radochová, 1975). However, the spheroplast fusion technique offers an alternative for studying the genetics of steroid-metabolizing Mycobacterium strains. Several methods have been published for the preparation of spheroplasts from $M$. tuberculosis (Thacore \& Willett, 1963; Dorozhkova \& Volk, 1972), from $M$. bovis BCG (Sato et al., 1965) and from different fast-growing mycobacteria (Adámek et al., 1969; Rastogi \& David, 1981; Rastogi et al., 1983a). Genetic recombinations have been carried out between carotenoid pigment mutants of $M$. aurum by spheroplast fusion (Rastogi et al., 1983b, 1986).

In this paper we describe experiments on the preparation and fusion of spheroplasts of auxotrophic and antibiotic-resistant mutants of fast-growing Mycobacterium strains with steroldegrading properties. The sterol-transforming properties of parent and recombinant strains are compared.

\section{METHODS}

Strains and growth conditions. Mycobacterium sp. NCAIM 00349 and Mycobacterium phlei NCAIM 00029 are deposited in the National Collection of Agricultural and Industrial Micro-organisms (Budapest). Cells were maintained on slants of glucose/potato medium, which contained $1 \%(\mathrm{w} / \mathrm{v})$ glucose, $3 \%(\mathrm{w} / \mathrm{v})$ potato starch and $2 \cdot 2 \%(w / v)$ agar.

Auxotrophic and antibiotic-resistant mutants of the Mycobacterium strains were obtained by MNNG mutagenesis. The bacteria were inoculated into nutrient broth $\left(6 \mathrm{~g}^{-1}\right.$, Difco) supplemented with Tween 80 $\left(0 \cdot 1 \%\right.$, and incubated overnight at $37^{\circ} \mathrm{C}$ with shaking. The cells were harvested by centrifugation, resuspended in $0.9 \%$ saline solution supplemented with $0.1 \%$ Tween 80 , and incubated at $32{ }^{\circ} \mathrm{C}$ for 80 min with $500-2000 \mu \mathrm{g}$ 
$N$-methyl- $N^{\prime}$-nitro- $N$-nitrosoguanidine (Sigma) $\mathrm{ml}^{-1}$. After incubation, the suspension was spread onto glucose/ potato agar plates and incubated at $32{ }^{\circ} \mathrm{C}$ for $5-7 \mathrm{~d}$; isolated colonies were tested for nutritional requirements. By mutagenic treatment of Mycobacterium sp. NCAIM 00349 we obtained auxotrophic strains, which require for growth adenine $\left(50 \mu \mathrm{g} \mathrm{ml}^{-1}\right)$, valine $\left(50 \mu \mathrm{g} \mathrm{ml}^{-1}\right)$ and proline $\left(50 \mu \mathrm{g} \mathrm{ml}^{-1}\right)$, respectively, and streptomycinresistant mutants able to grow on agar media containing $500 \mu \mathrm{g} \mathrm{ml}^{-1}$ streptomycin.

Spheroplast preparation and fusion. For preparation of wall-deficient forms the bacteria were grown at $32{ }^{\circ} \mathrm{C}$ for $48 \mathrm{~h}$ in shake flasks containing nutrient broth $\left(6 \mathrm{~g} \mathrm{l}^{-1}\right.$, Difco), then $1 \%$ of the precultured bacteria were inoculated and incubated for $16 \mathrm{~h}$ at $32{ }^{\circ} \mathrm{C}$ in nutrient broth medium containing glycine $1.5 \%(\mathrm{w} / \mathrm{v})$. Finally, a membranesterilized solution of vancomycin $\left(100 \mu \mathrm{g} \mathrm{m}^{-1}\right.$ final concentration) was added to the resulting culture and incubation was continued for a further $3 \mathrm{~h}$ at $37^{\circ} \mathrm{C}$. The wall-deficient forms obtained from $100 \mathrm{ml}$ cultures were harvested by centrifugation, washed three times with P buffer (Okanishi et al., 1974; Hopwood et al., 1985; but with $0.5 \mathrm{M}$-sucrose), resuspended in $4 \mathrm{ml} \mathrm{P}$ buffer containing lysozyme $\left(0.5-10 \mathrm{mg} \mathrm{ml}^{-1}\right)$ and incubated at $32^{\circ} \mathrm{C}$ for $180 \mathrm{~min}$ with continuous stiring. During this step, the decrease in turbidity of the bacterial suspension was monitored by measuring optical density at $620 \mathrm{~nm}$. After lysozyme treatment, the suspension was centrifuged at $700 \mathrm{~g}$ for $1 \mathrm{~min}$ at $20^{\circ} \mathrm{C}$ to remove cell debris, and the supernatant carefully decanted and centrifuged at $8000 \mathrm{~g}$ for $20 \mathrm{~min}$ at $20^{\circ} \mathrm{C}$ to collect the spheroplast pellets. Fusion was promoted by treating spheroplast pellets for $5 \mathrm{~min}$ with $1 \mathrm{ml} \mathrm{50 \% (w/v)} \mathrm{polyethylene} \mathrm{glycol} \mathrm{(PEG} \mathrm{6000,} \mathrm{Fluka} \mathrm{AG)} \mathrm{in} \mathrm{P} \mathrm{buffer,} \mathrm{followed} \mathrm{by} \mathrm{dilution} \mathrm{with} 4 \mathrm{ml}$ buffer $\mathrm{P}$ and plating on a non-selective agar medium (Hopwood $e t$ al., 1985). The basal regeneration medium contained sucrose $(171 \mathrm{~g}), \mathrm{K}_{2} \mathrm{SO}_{4}(0 \cdot 25 \mathrm{~g}), \mathrm{MgCl}_{2} \cdot 6 \mathrm{H}_{2} \mathrm{O}(10 \cdot 12 \mathrm{~g})$, glucose $(10 \mathrm{~g})$, Casamino acids (0.1 g, Difco), Bacto-agar $(22 \mathrm{~g}, \mathrm{Difco})$, and $800 \mathrm{ml}$ distilled water. After autoclaving, the following solutions were added to $80 \mathrm{ml}$ portions of

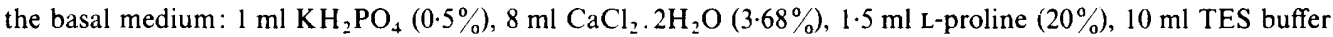
$(5.73 \%$, adjusted to $\mathrm{pH} 7.2), 0.2 \mathrm{ml}$ trace element solution, and $0.5 \mathrm{ml} 1 \mathrm{M}-\mathrm{NaOH}$. After the plates had been incubated for 5-7 d, the cells were re-suspended in distilled water and plated on a minimal medium containing glucose (10 g), $\mathrm{NH}_{4} \mathrm{NO}_{3}(1.0 \mathrm{~g}), \mathrm{K}_{2} \mathrm{HPO}_{4}(0 \cdot 25 \mathrm{~g}), \mathrm{MgSO}_{4}, 7 \mathrm{H}_{2} \mathrm{O}(0 \cdot 25 \mathrm{~g}), \mathrm{NaCl}(0.005 \mathrm{~g}), \mathrm{FeSO}_{4} \cdot 7 \mathrm{H}, \mathrm{O}(0 \cdot 001 \mathrm{~g})$, agar $(15 \mathrm{~g})$, distilled water to one litre, and combinations of growth factors selective for particular genotypes. Colonies were counted after $5 \mathrm{~d}$ incubation.

Electron microscopy. The wall-deficient forms and spheroplasts were fixed for $6 \mathrm{~h}$ in a solution containing $2 \%$ $(\mathrm{w} / \mathrm{v})$ formaldehyde and $1.25 \%(\mathrm{w} / \mathrm{v})$ glutaraldehyde (Sigma) in $\mathrm{KH}_{2} \mathrm{PO}_{4} / \mathrm{K}_{2} \mathrm{HPO}_{4}$ buffer $(100 \mathrm{~mm}, \mathrm{pH} 7 \cdot 1)$, followed by post-fixation in $2 \%(\mathrm{w} / \mathrm{v}) \mathrm{OsO}_{4}$, in $200 \mathrm{mM}-\mathrm{KH}_{2} \mathrm{PO}_{4} / \mathrm{K}_{2} \mathrm{HPO}_{4}$ buffer $(\mathrm{pH} 7 \cdot 1)$, for $2 \mathrm{~h}$. Ultrathin sections were prepared using an LKB IV ultramicrctome and stained according to Reynolds (1963).

Steroid-transforming properties of recombinant strains. Sterol transformations were carried out in $500 \mathrm{ml}$ flatbottomed flasks containing $100 \mathrm{ml}$ culture medium. The culture medium contained glycerol $(10 \mathrm{~g})$, urea $(0.5 \mathrm{~g})$, soybean flour $(2.0 \mathrm{~g}), \mathrm{CaCO}_{3}(3.0 \mathrm{~g}), \mathrm{NH}_{4} \mathrm{Cl}(3.0 \mathrm{~g}), \mathrm{KH}_{2} \mathrm{PO}_{4}(0.5 \mathrm{~g})$, and distilled water to one litre. A fine suspension of $20 \mathrm{~g}$ of a $2: 1$ mixture of $\beta$-sitosterol (I) and campesterol (II), $2 \mathrm{~g}$ Tween 80 and $6 \mathrm{~g}$ polypropylene glycol 2000 was dispersed by heating and added to 1 litre of the culture medium before autoclaving at $121^{\circ} \mathrm{C}$ for $20 \mathrm{~min}$. The sterile culture media were incculated with the Mycobacterium cells and shaken on a rotary shaker (deflection $2.5 \mathrm{~cm}, 320$ rotations $\min ^{-1}$ ) at $32{ }^{\circ} \mathrm{C}$ for $168 \mathrm{~h}$. At the end of the experiment the culture broth was extracted exhaustively with ethyl acetate.

The extracts were analysed by thin-layer chromatography, with Kieselgel $\mathrm{HF}_{254-366}$ (Merck) as adsorbent. The developing solvents were: A, ethyl acetate/n-heptane $(7: 3, v / v) ; B$, acetone/benzene $(1: 1, v / v)$. Detection was in UV light, and by conc. $\mathrm{H}_{2} \mathrm{SO}_{4}$ treatment, for the presence of the mixture of $\beta$-sitosterol (I) and campesterol (II) and the following microbial degradation products of these sterols: 3 -hydroxy-9,10-seco-1,3,5(10)-androstatriene-9,17dione (III); 1,4-androstadiene-3,17-dione (IV); $9 \alpha$-hydroxy-4-androstene-3,17-dione (V); $9 \alpha, 17 \beta$-dihydroxy4-androsten-3-one (VI); $9 \alpha$-hydroxy-3-oxo-23,24-dinor-4-cholen-22-oic acid (VII) and its methyl ester (VIII); $9 \alpha$-hydroxy-3-oxo-23,24-dinor-4,17(20)-choladien-22-oic acid (IX); 9 $\alpha, 22$-dihydroxy-23,24-dinor-4-cholen-3-one (X); 9 9-hydroxy-3-oxo-23,24-dinor-4,17(20)-choladien-22-al (XI); $9 \alpha$-hydroxy-26,27-dinor-4-cholestene-3,24dione (XII); $9 \alpha$-hydroxy-27-nor-4-cholestene-3,24-dione (XIII); mixture of 3-oxo-4-stigmasten-26-oic acid (XIV) and 3-oxo-(24R)-24-methyl-4-cholesten-26-oic acid (XV) and methyl esters of compounds XIV and XV (XVI and XVII); $9 \alpha$-hydroxy-3-oxo-4,24(25)-stigmastadien-26-oic acid (XVIII) and its methyl ester (XIX); 4-stigmasten-3one (XX); (24R)-24-methyl-4-cholesten-3-one (XXI). Approximate $R_{F}$ values were as follows. System A : I, $0 \cdot 81$;

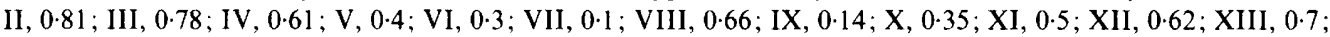
XIV, $0 \cdot 75 ; \mathrm{XV}, 0 \cdot 75 ; \mathrm{XVI}, 0.86 ; \mathrm{XVII}, 0 \cdot 86$; XVIII, $0 \cdot 47$; XIX, $0.78 ; \mathrm{XX}, 0.9 ; \mathrm{XXI}, 0.9$. System B: VII, $0 \cdot 4$; VIII, $0.79 ; \mathrm{IX}, 0.5 ; \mathrm{X}, 0.56 ; \mathrm{XI}, 0.75$.

The microbial degradation products were isolated from the culture broths of both fusion partners, regenerated single strains and some selected recombinant strains. Ethyl acetate extracts obtained from the cultures were evaporated in vacuo. The microbial transformation products were separated by column chromatography (adsorbent, silicic acid; eluent, ethyl acetate/n-hexane with gradually increasing ethyl acetate content) and by preparative TLC (adsorbent, Kieselgel $\mathrm{HF}_{254 \cdot 366}$; developing solvents as described above; elution of compounds with methanol). 
The following compounds were identified by comparison with authentic standards (UV, IR, TLC, GLC): I, II, III, IV, V, XX and XXI. Compounds VI, VII, VIII, IX, X, XI, XII, XIII were identified by comparison with

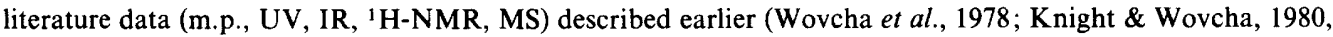
1984). The closely related transformation products XIV and XV were isolated as a mixture in which compound $\mathrm{XIV}$ is the main component as shown by mass spectrometry (XIV M+.442; XV M+.428). These compounds are described in the literature (Fujimoto et al., 1982a,b). Compounds XVI and XVII were also obtained as a mixture which proved to be identical with the product of esterification of the mixture of XIV and XV carried out by diazomethane. The structures of compound XVIII and its methyl ester (XIX) were elucidated by UV, IR, ${ }^{1} \mathrm{H}$ NMR, ${ }^{13} \mathrm{C}-\mathrm{NMR}$ and mass spectroscopy. Compound XVIII. UV: $\lambda_{\max } 239 \mathrm{~nm},\left(\varepsilon=213001 \mathrm{~mol}^{-1} \mathrm{~cm}^{-1}\right)$ (overlapping absorption maxima of 4-en-3-one and 24-en-26-oic acid chromophores). MS: $\mathrm{M}^{+} \cdot 456$; [M$\left.\mathrm{H}_{2} \mathrm{O}\right]^{+\cdot}=438$ (base peak); $\left[\mathrm{M}-\mathrm{H}_{2} \mathrm{O}-\mathrm{CO}\right]^{+\cdot}=410 ; m / z=124$ (ring $\mathrm{A}+\mathrm{C}_{6}$ fragment). Compound XIX. UV: $\lambda_{\max }$ $239 \mathrm{~nm},\left(\varepsilon=21500 \mathrm{l} \mathrm{mol}^{-1} \mathrm{~cm}^{-1}\right)$. MS: $\mathrm{M}+470 ;\left[\mathrm{M}-\mathrm{CH}_{3} \mathrm{OH}\right]+\cdot=438 ;\left[\mathrm{M}-\mathrm{CH}_{3} \mathrm{OH}-\mathrm{CO}\right]+\cdot=410 ; m / z=124$ (base peak). Structure determination of XVIII and XIX in detail will be published separately.

\section{RESULTS}

\section{Preparation and regeneration of spheroplasts}

The cell walls of the Mycobacterium strains studied could not be removed directly by lysozyme treatment. Pre-treatment with glycine and vancomycin, added to exponential-phase cultures, promoted the hydrolytic effect of lysozyme on the cell wall. Glycine and vancomycin each inhibited the growth of Mycobacterium sp. NCAIM 00349 (Fig. 1); the maximal inhibitory effect was observed when both glycine and vancomycin were added.

On the basis of this observation we have developed a suitable method for spheroplast preparation from fast-growing Mycobacterium strains. After incubation with glycine $(1.5 \%, \mathrm{w} / \mathrm{v})$ and vancomycin $\left(100 \mu \mathrm{g} \mathrm{ml}^{-1}\right)$, the cells of Mycobacterium sp. NCAIM 00349 were digested with lysozyme $\left(10 \mathrm{mg} \mathrm{ml}^{-1}\right)$. As shown in Fig. 2, some fragments of the cell wall remained attached to the membrane, hence most of the cells were converted to spheroplasts rather than true protoplasts. The enzymic hydrolysis resulted in conversion of approximately $85 \%$ of the cells into spheroplasts.

The optimal temperature of regeneration of spheroplasts of Mycobacterium $\mathrm{sp}$. NCAIM 00349 was $32^{\circ} \mathrm{C}$. The first visible colonies from regenerated spheroplasts appeared after 3-4 d incubation. The rate of spheroplast regeneration was about $8 \times 10^{-1}$.

The above method for spheroplast preparation was also found to be suitable for Mycobacterium phlei NCAIM 00029 , using $0.2 \%(\mathrm{w} / \mathrm{v})$ glycine, $100 \mu \mathrm{g}$ vancomycin $\mathrm{ml}^{-1}$, and $500 \mu \mathrm{g}$ lysozyme $\mathrm{ml}^{-1}$.

\section{Spheroplast fusions}

In order to perform spheroplast fusion experiments we used genetically marked strains of Mycobacterium sp. NCAIM 00349. We compared the frequencies of prototrophic recombinants obtained by treating Mycobacterium sp. NCAIM 00349 auxotrophic strains with PEG 1000 and PEG 6000 in concentrations ranging from 30 to $60 \%(\mathrm{w} / \mathrm{v})$. When spheroplasts were treated with $50 \%$ PEG 1000 at $32{ }^{\circ} \mathrm{C}$ for $5 \mathrm{~min}$, the recombination frequency was $3.5 \times 10^{-3}$ prototrophic recombinants per initial (unfused) spheroplast, whereas a frequency of $6.4 \times 10^{-2}$ was obtained after treatment with $50 \%$ PEG 6000 .

The fusion partners and crosses in two of the fusion experiments were the following. In the first experiment the Ade- $\mathrm{Str}^{\mathrm{S}}$ mutant of Mycobacterium sp. NCAIM 00349 was fused with the $\mathrm{Ade}^{+} \mathrm{Str}^{\mathrm{R}}$ mutant. In the second fusion experiment the $\mathrm{Ade}^{+} \mathrm{Str}^{\mathrm{S}}$ and $\mathrm{Ade}^{-} \mathrm{Str}^{\mathrm{R}}$ mutants were the parents. Analysis of colonies obtained by cell wall regeneration after the fusion experiments gave the following results. In the first experiment we examined 2500 regenerated colonies: 159 $\mathrm{Ade}^{+} \mathrm{Str}^{\mathrm{S}}$ prototrophic recombinants and $11 \mathrm{Ade}^{-} \mathrm{Str}^{\mathrm{R}}$ double-markered recombinants were found. In the second experiment we obtained $34 \mathrm{Ade}^{-} \mathrm{Str}^{\mathrm{S}}$ and $23 \mathrm{Ade}^{+} \mathrm{Str}^{\mathrm{R}}$ recombinants from the analysis of 3700 regenerated spheroplasts. 


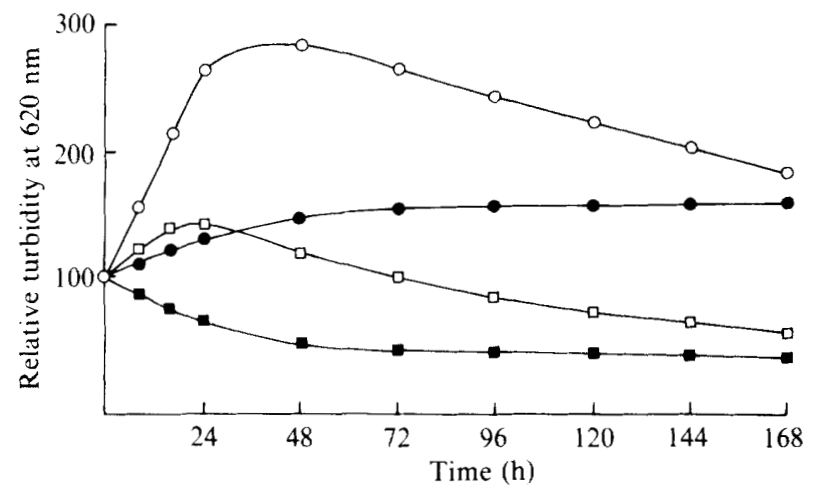

Fig. 1. Lytic effect of vancomycin and glycine added to cultures of Mycobacterium sp. NCAIM 00349. $\mathrm{O}$, Control (no addition);, $1.5 \%$ glycine; $\square, 100 \mu \mathrm{g}$ vancomycin $\mathrm{ml}^{-1} ; \square, 100 \mu \mathrm{g}$ vancomycin $\mathrm{ml}^{-1}+1 \cdot 5 \%$ glycine.

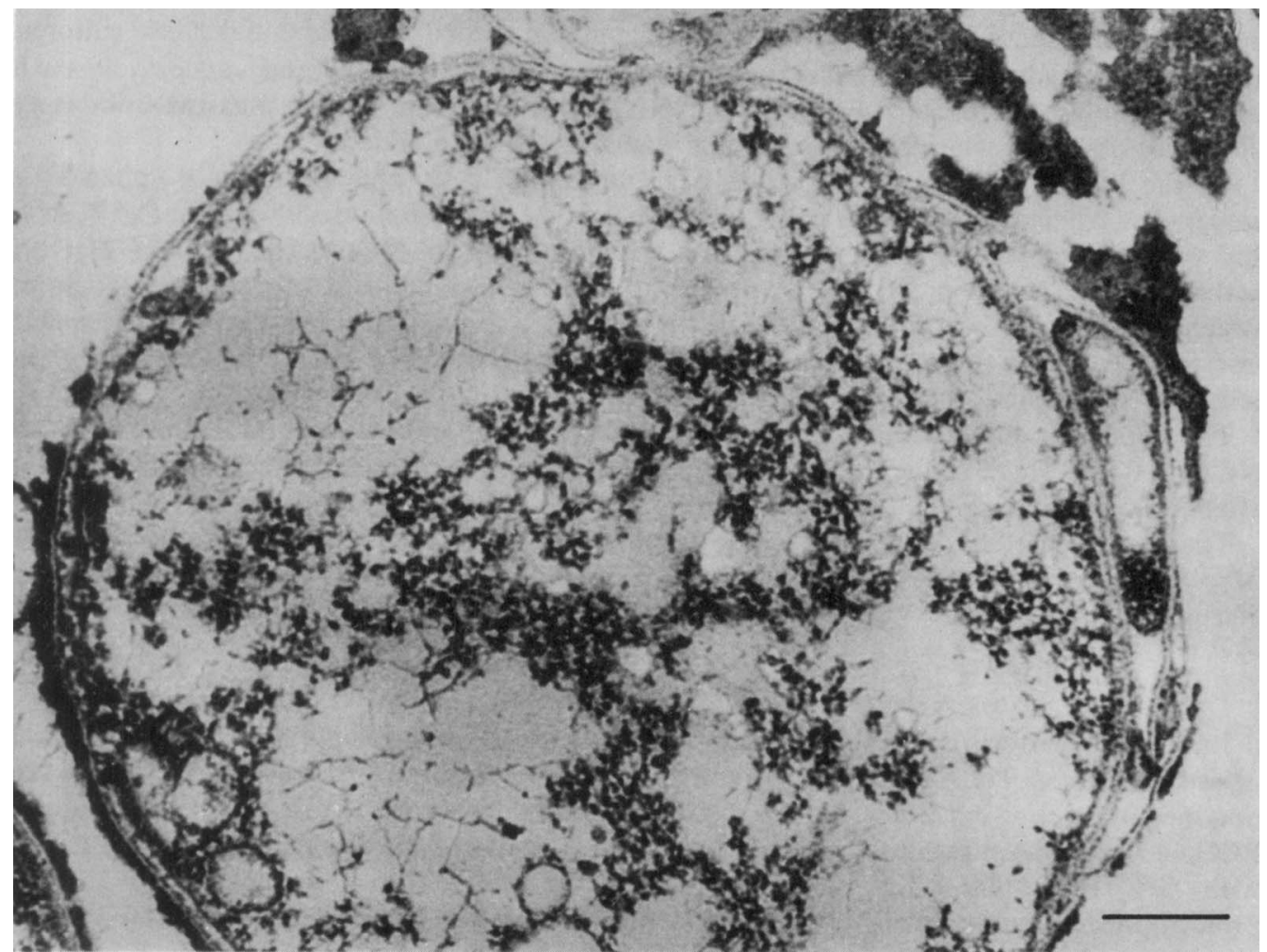

Fig. 2. Electron micrograph of a thin section of a spheroplast obtained from Mycobacterium sp. NCAIM 00349. Bar, $0 \cdot 1 \mu \mathrm{m}$.

\section{Sterol-transforming properties of recombinant strains}

We studied the sterol-transforming properties of $525 \mathrm{Ade}^{+} \mathrm{Str}^{\mathrm{S}}$ recombinant strains obtained in four crosses carried out between the mutants $\mathrm{Ade}^{-} \mathrm{Str}^{\mathrm{S}}$ and $\mathrm{Ade}^{+} \mathrm{Str}^{\mathrm{R}}$ of Mycobacterium sp. NCAIM 00349. The parent strains produced $9 \alpha$-hydroxy-4-androstene-3,17-dione (V) as a main product and mixture of compounds VII, VIII, IX, X and XI formed in smaller amount from 


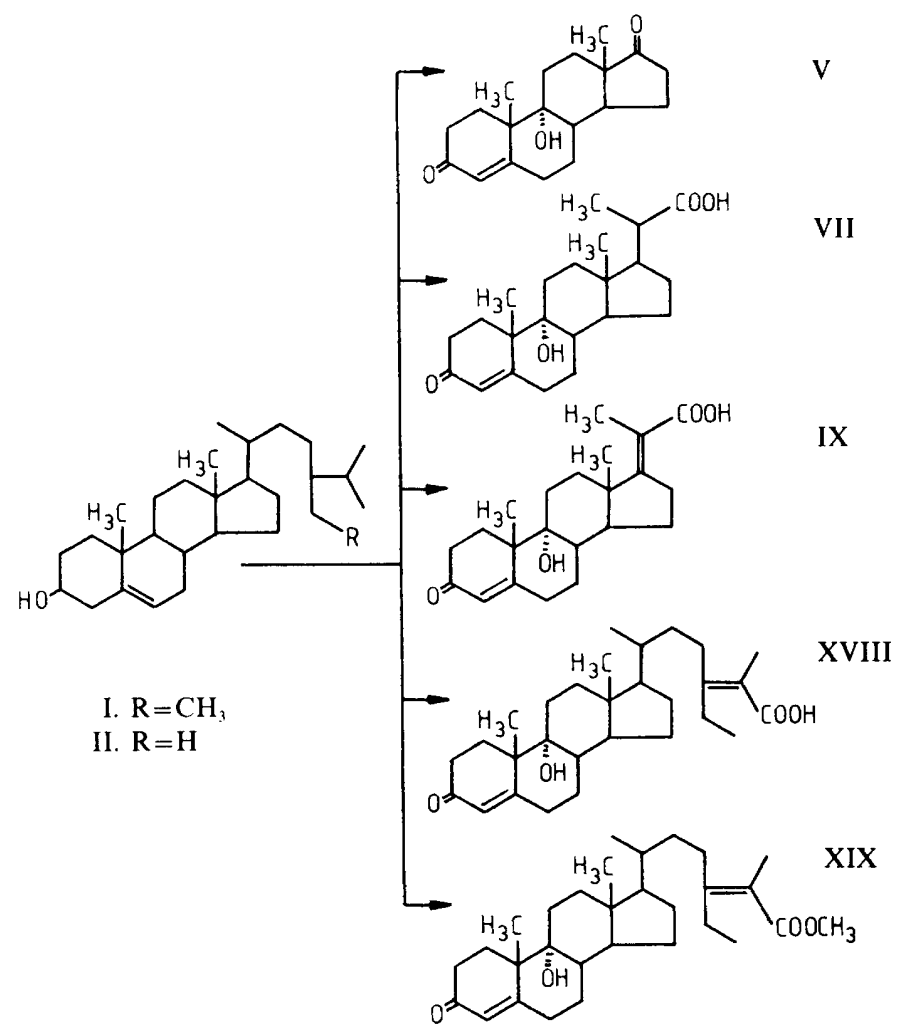

Fig. 3. Characteristic transformation products accumulated from phytosterols with Mycobacterium strains obtained by the spheroplast fusion technique.

commercially available sitosterol [ $2: 1$ mixture of $\beta$-sitosterol (I) and campesterol (II)]. Traces of compounds III and VI were also observed among the degradation products accumulated. The ratio of compound $\mathrm{V}$ to the total amount of the by-products was $3: 1$ for both parent strains. Five per cent of the recombinants showed significant changes in sitosterol-degrading ability compared to that of their parents. Most of the selected strains produced the same degradation products, but the proportions differed from those produced by the parent strains. Two recombinant strains did not accumulate $9 \alpha$-hydroxy-4-androstene-3,17-dione (V) at all and gave a mixture of dinorcholanoic acids (VII and IX) in high yield and compounds VIII, X and XI as minor components during transformation. One recombinant strain yielded transformation products XII, XIII, XIV, XV, XVI, XVII, XVIII, XIX, XX and XXI derived from the initial stages of the side-chain degradation pathway. Compounds XVIII and XIX are new sterol degradation products. Among the recombinants we found two strains which were not able to transform sitosterol at all. In some transformations carried out with regenerated spheroplasts we also observed changes in the ratio of conversion products when compared to non-spheroplasted strains.

\section{DISCUSSION}

Peptidoglycan biosynthesis in the bacterial cell wall consists of three stages: biosynthesis of uridine nucleotide precursors; utilization of these precursors to form peptidoglycan strands; and cross-linking of the linear strands. Each of these stages is specifically inhibited by certain antibiotics and amino acids. We have found that the antibiotic vancomycin, which inhibits the second stage of peptidoglycan biosynthesis (Siewert \& Strominger, 1967), stimulates the 
formation of wall-deficient forms of mycobacteria. Previously glycine, which is incorporated into the uridine nucleotide precursors in place of L-alanine (Strominger \& Birge, 1965), has been widely used for preparation of wall-deficient forms of mycobacteria (Sato et al., 1965; Adámek et al., 1969; Rastogi \& David, 1981). In our experiments, the concerted action of glycine and vancomycin afforded wall-deficient cells which could readily be attacked with lysozyme for hydrolysis of the glycoside bonds of the carbohydrate strands.

Genetic recombination by protoplast fusion in Streptomyces was described by Hopwood et al. (1977), and the technique developed by Baltz (1978). The methods elaborated for protoplast fusion in Streptomyces can clearly be utilized for fast-growing mycobacterial strains. Protoplasts obtained from Streptomyces fradiae and Streptomyces griseofuscus grown to the late exponential phase regenerate efficiently (Baltz, 1978); the protoplast regeneration and fusion efficiencies are strongly influenced by the incubation temperatures for cell growth and protoplast regeneration (Baltz \& Matsushima, 1981). We have shown that spheroplasts can be prepared in high yield from mycobacteria grown to the late exponential phase. After optimization of temperature for cell growth and spheroplast regeneration we obtained genetic recombinations at frequencies of 2-6 $\times 10^{-2}$, similar to the frequencies described in Streptomyces (Hopwood et al., 1977).

After simple regeneration of spheroplasts we obtained some strains with modified steroltransforming properties, but they occurred at much lower frequencies than when spheroplast fusion was promoted by adding polyethylene glycol. Among the recombinants obtained by the spheroplast fusion method we found a strain that accumulated new transformation products which could be fitted into the microbial degradation pathway of sitosterol elucidated by Sih and coworkers (Fujimoto et al., 1982a,b). Our method could be applied to isolate strains which produce $9 \alpha$-hydroxy-4-androstene-3,17-dione (V), the known intermediate of corticosteroid synthesis (Dodson \& Muir, 1961; Van Rheenen \& Shephard, 1979), from phytosterols at higher yields than the parent strains and to select strains which transform $\beta$-sitosterol (I) and campesterol (II) into $9 \alpha$-hydroxy-3-oxo-23,24-dinor-4-cholen-22-oic acid (VII) and $9 \alpha$-hydroxy3-oxo-23,24-dinor-4,17(20)-choladien-22-oic acid (IX), useful starting materials for synthesis of steroid drugs with a pregnane side chain (Kieslich, 1985) (see Fig. 3).

Consequently, spheroplast fusion seems to be a promising technique for strain improvement programmes for mycobacterial transformation of steroids.

The authors wish to thank Professor D. A. Hopwood for helpful discussions.

\section{REFERENCES}

AdámeK, L., Mišoň, P., Mohelská, H. \& TRnKa, L. (1969). Ultrastructural organization of spheroplasts induced in Mycobacterium sp. smegmatis by lysozyme or glycine. Archiv für Mikrobiologie 69, 227-236.

AmBrus, G. \& BüKI, K. G. (1969). Degradation of sapogenins by Mycobacterium phlei. Steroids 13, 623-625.

BALTZ, R. H. (1978). Genetic recombination in Streptomyces fradiae by protoplast fusion and cell regeneration. Journal of General Microbiology 107, 93-102.

Baltz, R. H. \& Matsushima, P. (1981). Protoplast fusion in Streptomyces: conditions for efficient genetic recombination and cell regeneration. Journal of General Microbiology 127, 137-146.

Dodson, R. M. \& MUIR, R. D. (1961). Microbiological transformations. VII. The hydroxylation of steroids at C-9. Journal of the American Chemical Society 83, 4631-4635.

Dorozhkova, I. R. \& Volk, A. V. (1972). Induction rate of L-form in Mycobacterium tuberculosis under the effect of cycloserine and its combinations with other drugs. Antibiotiki 17, 838-844.
Fujimoto, Y., Chen, C.-S., Szeleczky, Z., Di Tullio D. \& SiH, C. J. (1982a). Microbial degradation of the phytosterol side chain. 1. Enzymatic conversion of 3-oxo-24-ethylcholest-4-en-26-oic acid into 3-oxochol-4-en-24-oic acid and androst-4-ene-3,17-dione. Journal of the American Chemical Society 104, 47184720.

Fujimoto, Y., Chen, C.-S., Gopalan, A. S. \& Sih, C. J. (1982b). Microbial degradation of the phytosterol side chain. 2. Incorporation of $\mathrm{NaH}^{14} \mathrm{CO}_{3}$ onto the C-28 position. Journal of the American Chemical Society 104, 4720-4722.

Habets-Crutzen, A. Q. H., Carlier, S. J. N., De Bont, J. A. M., Wistuba, D., Schurig, V., Hartmans, S. \& Tramper, J. (1985). Stereospecific formation of 1,2-epoxypropane, 1,2-epoxybutane and 1-chloro-2,3-epoxypropane by alkene-utilizing bacteria. Enzyme and Microbial Technology 7, 17-21.

Hopwood, D. A., Bibb, J. M., Chater, K. F., Kieser, T., BRUTON, C. J., KiESER, M. M., LYDIATE, D. J., Smith, C. P., Ward, J. M. \& Schrempf, H. (1985). Genetic Manipulation of Streptomyces : a Laboratory Manual. Norwich: John Innes Foundation. 
Hopwood, D. A., Wright, H. M., BibB, M. J. \& CoHEN, S. N. (1977). Genetic recombination through protoplast fusion in Streptomyces. Nature, London 268, 171-174.

KIESLICH, K. (1985). Microbial side-chain degradation of sterols. Journal of Basic Microbiology 25, 461-474.

KNIG̀HT, J. C. \& Wovcha, M. G. (1980). Microbial degradation of the phytosterol side-chain to 24-oxoproducts. Steroids 36, 723-730.

KNIGHT, J. C. \& WovchA, M. G. (1984). Isolation and quantitation of 9-hydroxy-3-oxo-23,24-dinor$4,17(20)$-choladien-22-al from a sitosterol bioconversion. In Advances in Steroid Analysis '84, pp. 479-484. Edited by S. Görög. Amsterdam: Elsevier.

KONIČEK, J. \& KONIČKOVA-RADOCHOVÁ, M. (1975). Possibilities of the conjugation process in mycobacteria. Folia microbiologica 20, 382-388.

Marsheck, W. J., KRAYChY, S. \& MUIR, R. D. (1972). Microbial degradation of sterols. Applied Microbiology 23, 72-77.

Mizuguchi, Y. \& Tokunaga, T. (1971). Recombination between Mycobacterium smegmatis strains Jucho and Lacticola. Japanese Journal of Microbiology 15, 359-366.

OKanishi, M., Suzuki, K. \& Umezawa, H. (1974). Formation and reversion of streptomycete protoplasts: culture conditions and morphological study. Journal of General Microbiology 80, 389-400.

RastoGI, N. \& DAvid, H. L. (1981). Ultrastructural and chemical studies on wall-deficient forms, spheroplasts and membrane vesicles from Mycobacterium aurum. Journal of General Microbiology 124, 71-79.

Rastogi, N., Lévy-Frébault, V. \& David, H. L. (1983a). Spheroplast formation from nine rapidlygrowing mycobacteria. Current Microbiology 9, 201204.

Rastogi, N., David, H. L. \& Rafidinarivo, E. $(1983 b)$. Spheroplast fusion as a mode of genetic recombination in mycobacteria. Journal of General Microbiology 129, 1227-1237.

Rastogi, N., Rauzier, J. Y., Papa, F. P. \& David,
H. L. (1986). Biochemical and cultural analysis of mycobacterial recombinants obtained by spheroplast fusion. Annales de microbiologie 137A, 135-142.

REYNOLDS, E. S. (1963). The use of lead citrate at high $\mathrm{pH}$ as an electron opaque stain in electron microscopy. Journal of Cell Biology 32, 27.

Sato, H., Diena, B. B. \& GreenberG, L. (1965). Spheroplast induction and lysis of BCG strains by glycine and lysozyme. Canadian Journal of Microbiology 12, 255-261.

SCHUbERT, K., BöHME, K.-H. \& HöRhOLd, C. (1961). Bildung einer Katosäure durch mikrobiellen Abbau von Progesteron. Hoppe-Seyler's Zeitschrift für Phy. siologische Chemie 325, 260-262.

SiEwert, G. \& Strominger, J. L. (1967). Bacitracin: an inhibitor of the dephosphorylation of lipid pyrophosphate, an intermediate in biosynthesis of the peptidoglycan of bacterial cell walls. Proceedings of the National Academy of Sciences of the United States of America 57, 767-773.

Strominger, L. \& Birge, C. H. (1965). Nucleotide accumulation induced in Staphylococcus aureus by glycine. Journal of Bacteriology 89, 1124-1127.

ThaCORE, H. \& WilletT, H. P. (1963). Formation of spheroplasts of Mycobacterium tuberculosis by lysozyme treatment. Proceedings of the Society for Experimental Biology and Medicine 114, 43-47.

VAN Rheenen, V. \& Shephard, K. P. (1979). New synthesis of corticosteroids from 17-keto steroids: application and stereochemical study of the unsaturated sulfoxide-sulfonate rearrangement. Journal of Organic Chemistry 44, 1582-1584.

WIX, GY., BÜKI, K. G., TÖMÖRKÉNY, E. \& AMBrus, G. (1968). Inhibition of steroid nucleus degradation in mycobacterial transformations. Steroids 11, 401413.

Wovcha, M. G., Antosz, F. J., Knight, J. C., KOMINEK, L. A. \& PYKE, T. R. (1978). Bioconversion of sitosterol to useful steroidal intermediates by mutants of Mycobacterium fortuitum. Biochimica et biophysica acta 531, 308-321. 